\title{
IMPLEMENTASI POSITIVE REWARD DAN FACEBOOK UNTUK MENINGKATKAN KUALITAS DIALOG MAHASISWA
}

\author{
Habibi \\ Universitas Wiraraja \\ Habibi.bk13@Gmail.com
}

\begin{abstract}
ABSTRAK
Penelitian ini bertujuan untuk mengujicoba metode dan instrumen penguatan dialog perkuliahan yang dapat meningkatkan kualitas dialog mahasiswa dalam perkuliahan, dengan menggunakan prinsip penggunaan positive reward dan facebook. Jenis penelitian ini adalah eksperimental. Desain implementasi menggunakan desain preeksperimental yaitu one group pretest posttest design. Penelitian dilakukan pada mahasiswa Prodi Pendidikan IPA Universitas Wiraraja. Instrumen pengumpulan data adalah Lembar pencatatan keaktifan mahasiswa dan pembuatan group facebook. Teknik analisis data yang digunakan adalah tekinik analisis deskriptif untuk menjelaskan partisipasi, uji wilcoxon untuk mengukur perbedaan rasa percaya diri mahasiswa sebelum dan setelah perlakuan (dalam penelitian ini setelah empat kali tatap muka perkuliahan). Hasilnya menunjukkan bahwa partisipasi mahasiswa melalui facebook melebihi partisipasi mahasiswa dalam dialog di kelas. Pada aspek efikasi diri, dengan menggunakan uji Wilcoxson diperoleh adanya perbedaan yang signifikan ( $p$ value $=0,012>0,05$ ) antara sebelum perlakuan dengan beberapa waktu setelah penerapan metode dialog mahasiswa menggunakan positive reward dan facebook.
\end{abstract}

Kata Kunci: Dialog, positive reward, facebook

\section{PENDAHULUAN}

Aktivitas belajar peserta didik tidak hanya berupa aktivitas yang membutuhkan gerak dan keterampilan motorik (hands on activity) tetapi juga berupa aktivitas yang membuat mereka dapat menggunakan fungsi pikirannya (minds on activity) diantaranya adalah memahami, menganalisis dan mengkomunikasikan informasi-informasi terkait materi yang dipelajari. Demikian pula proses belajar akhirnya dapat juga kita lihat sebagai proses interaksi sosial yang unsur utamanya adalah komunikasi. Vygotsky melalui teori mediasi kognitif (Habibi, 2012) menekankan pada semua praktisi pendidikan betapa pentingnya interaksi sosial untuk keberhasilan proses pembelajaran. Melalui proses mediasi tersebut pengajar membimbing dan mengarahkan para peserta didik untuk meningkatkan kemampuan kognitifnya umumnya dengan menggunakan komunikasi atau dialog.
Dialog atau interaksi ilmiah dalam perkuliahan menjadi salah satu penentu kualitas keberhasilan belajar mahasiswa. Dalam interaksi dialogis ini akan terjadi konstruksi pemahaman dalam diri mahasiswa secara bermakna. Menurut Piaget (dalam Omrod, 2012) perkembangan kognitif manusia terjadi terutama ketika terjadi konflik kognitif sehingga menyebabkan ketidakseimbangan (disequilibrium). Ketidakseimbangan tersebut akan memicu proses penyeimbangan kembali melalui dua cara yaitu asimilasi (keseimbangan disesuaikan pada pemahaman yang telah dimiliki) dan akomodasi (keseimbangan disesuaikan pada informasi yang baru diperoleh). Adapun dalam dialog konflik terjadi antara dua atau lebih ide dan informasi dari masing-masing yang terlibat dalam dialog.

Chapin, O'chonnor dan Anderson (2003) memaparkan bagaimana awal dari perubahan kognitif yang terjadi pada 
siswa yang terlibat dalam dialog atau diskusi. Pada saat memulai dialog seorang anak yang berbicara, bertanya atau berargumen mengenai suatu tema atau materi pelajaran akan menyadari jika ternyata pemahamannya belum memadai. Dalam kehidupan sehari-hari ini mungkin sering kita alami, sesuatu yang telah kita anggap pahami ternyata tidaklah cukup ketika kita diminta menjelaskan atau mendiskusikannya. Saat hendak berbicara itulah kita menjadi sadar bahwa pemahaman kita belum cukup.

Peningkatan level kognitif dalam dialog juga dapat terjadi ketika seseorang memiliki keharusan seseorang untuk membuktikan apa yang menjadi klaimnya secara logis. Dengan demikian ia akan belajar untuk berpikir secara logis. Selanjutnya bukti-bukti rasional harus dapat digali untuk mendukung pendapatnya (Chapin, O'chonnor \& Anderson, 2003). Demikian pula saat mengajukan pertanyaan, seseorang harus dapat menganalisis fakta atau penjelasan dari orang lain atau kejadian tertentu sebelum ia mengajukan pertanyaan yang baik dan dipahami oleh rekan diskusinya.

Penelitian pada tahapan analisis dan desain (Habibi, 2014) yang dilakukan sebelumnya mendapatkan temuan bahwa kendala utama yang dialami mahasiswa prodi pendidikan IPA Universitas Wiraraja untuk berpatisipasi dalam dialog perkuliahan meliputi tiga hal yaitu rasa kurang percaya diri, pujian non spesifik dari dosen dan waktu dialog dalam perkuliahan yang terbatas. Ketiga kendala utama tersebut menjadi landasan pengembangan metode dan instrumen perkuliahan untuk meningkatkan kualitas dialog ilmiah mahasiswa.

Kelemahan kurangnya waktu dialog dalam pembelajaran salah satunya dapat diatasi dengan penggunaan teknologi komunikasi berbasis internet. salah satu teori belajar yang berkaitan dengan penggunaan teknologi informasi dalam proses pembelajaran adalah teori sosiokognitif dan teori konstruktivisme sosial. Dalam teori sosiokognitif berbagai model yang disajikan atau dilihat melalui media internet dapat memberikan suatu pengaruh terhadap pola berpikir atau sikap seseorang (modelling). Sedangkan dalam teori konstruktivisme sosial proses perubahan dan perkembangan kognitif serta perilaku dapat berlangsung melalui sharing atau komunikasi dengan orang lain baik secara langsung maupun melalui teknologi informasi. Kekuatan dari media ini juga karena dapat mengurangi batasan ruang dan waktu. Komunikasi yang biasanya hanya dapat dilakukan di kelas menjadi lebih luas dan hampir tak terbatas.

Metode yang dikembangkan dalam penelitian ini adalah membuka forum dialog di luar perkuliahan dengan menggunakan facebook dengan penguatan berupa pujian spesifik dan nilai menggunakan prinsip positive reward. Metode tersebut dikembangkan berdasarkan teori penguatan positif (positive reinforcement) yang diungkapkan oleh Skinner (Omrod, 2012). Dalam penguatan positif perilaku yang ingin dikuatkan terus diberikan stimulus yang menyenangkan pelaku sehingga pada akhirnya mereka menjadi terbiasa untuk melakukan aktivitas tersebut (terjadi proses pembiasaan yang oleh Skinner disebut dengan pembiasaan operan).

Implementasi dialog melalui facebook dan penguatan menggunakan positive reward dalam penelitian ini bertujuan untuk meningkatkan kualitas dialog dan efiksi diri mahasiswa dalam perkuliahan, dengan menggunakan prinsip positive reward (pemberian nilai dan pujian spesifik) dan social network (penggunaan facebook).

\section{METODE}

Penelitian ini merupakan termasuk ke dalam jenis penelitian eksperimen khususnya preeksperimental dengan tujuan untuk menganalisis pengaruh 
penerapan positive reward dan penggunaan facebook terhadap kualitas dialog mahasiswa. Kualitas dialog diukur dari dua indikator yaitu jumlah partisipasi mahasiswa dalam dialog dan perbedaan kepercayaan diri mahasiswa untuk mengikuti dialog sebelum dan setelah perlakuan. Penelitian dilakukan selama empat bulan di Prodi Pendidikan IPA Universitas Wiraraja Sumenep, khususnya pada mata kuliah Teori Belajar dengan jumlah mahasiswa sebanyak 22 orang.

Pengambilan data untuk partisipasi mahasiswa adalah dengan menggunakan instrumen Lembar Pencatatan Keaktifan Mahasiswa dan group facebook. Data kepercayaan diri mahasiswa diperoleh dengan menggunakan instrument pengukuran efikasi diri dialog kuliah. Pengambilan data efikasi diri dilakukan dua kali yaitu pada pertemuan pertama dan setelah pertemuan keempat. Penentuan waktu ini disesuaikan dengan skedul penelitian Universitas.

Teknik analisis data yang digunakan dalam penelitian ini adalah meliputi dua jenis yaitu:

1. Analisis partisipasi mahasiswa pada diskusi baik di kelas maupun melalui facebook. Analisis menggunakan statistik deskriptif, mengenai bagaimana kondisi diskusi di kelas dan facebook baik pada aspek persentase mahasiswa yang terlibat, persentase mahasiswa yang tidak aktif dalam dialog dan perubahan kuantitas peserta dialog setiap minggu (minggu kedua hingga kelima).

2. Analisis perbedaan kepercayaan diri mahasiswa dalam menyusun kalimat antara sebelum treatment dan sesudah treatment. Analisis ini bertujuan untuk mengetahui bagaimana efek penerapan metode dan instrumen yang dikembangkan terhadap rasa percaya diri mahasiswa dalam dialog. Data kepercayaan diri diperoleh dari hasil pengisian Instrumen Efikasi Diri dalam Dialog Kuliah yang dikembangkan oleh peneliti dengan mengadaptasi instrument sejenis yang dikembangkan oleh Gaffney (2011). Perbedaan efikasi mahasiswa dalam dialog diuji dengan menggunakan uji beda dengan terlebih dahulu melakukan pengukuran normalitas dan homogenitas data.

\section{HASIL DAN PEMBAHASAN}

\section{Partisipasi Mahasiswa dalam Dialog} perkuliahan menggunakan positive reinforcement dan social network seperti yang telah dipapar pada bab dua tersusun atas dua proses diskusi yaitu diskusi di dalam kelas dan diskusi di luar kelas menggunakan facebook. Jumlah pertemuan yang dianalisis dalam penelitian ini adalah empat pertemuan (empat minggu). Tabulasi data partisipasi mahasiswa dalam dialog dapat dilihat pada Tabel 1.

Tabel 1. Tabulasi Data Partisipasi Mahasiswa dalam Dialog

\begin{tabular}{lccccc}
\hline \multicolumn{7}{c}{ Jumlah } & Mahasiswa & Berpartisipasi/ Pertemuan & \\
\hline & I & II & III & IV & Rata-rata \\
\hline Dialog di Kelas & 2 & 15 & 7 & 8 & 8 \\
\hline Dialog di FB & 13 & 20 & 15 & 17 & 16.25 \\
\hline
\end{tabular}

Rata-rata jumlah partisipasi mahasiswa dalam dialog di keempat minggu menunjukkan bahwa dialog melalui FB berjumlah dua kali lipat partisipasi mahasiswa dalam dialog di dalam kelas. Angka patisipasi menunjukkan jumlah mahasiswa yang terlibat dalam dialog, bukan 
menunjukkan jumlah pertanyaan atau jawaban dalam dialog tersebut. Hal ini dilakukan untuk menghindari angka partispasi yang semu (jumlah interaksi besar namun sebenarnya mahasiswa yang terlibat sedikit). Secara lebih detail proporsi ini terjadi konstan selama empat minggu. Ketersediaan waktu tampaknya menjadi penyebab utama perbedaan ini.

Secara keseluruhan jumlah mahasiswa yang menjadi subyek penelitian ini adalah 22 mahasiswa. Dari jumlah mahasiswa tersebut didapatkan data bahwa satu mahasiswa tidak mendaftarkan diri sebagai anggota kelompok dialog di FB. Hal ini dapat terjadi karena partisipasi dalam dialog memang mendapatkan penilaian namun bukan merupakan kewajiban. Hampir keseluruhan anggota kelas yang mendaftarkan diri dalam kelompok dialog di FB menunjukkan bahwa media sosial ini telah menjadi media yang umum di kalangan remaja khususnya mahasiswa.

Jumlah partisipasi di FB sebanyak dua kali lipat dari partisipasi dalam dialog di kelas juga menunjukkan hasil positif penggunaan social network di internet untuk meningkatkan kuantitas dialog mahasiswa dalam perkuliahan. Hal ini tetap terjadi meskipun pada dialog di dalam kelas juga diberikan reward berupa nilai. Jumlah partisipasi mahasiswa dalam empat minggu yang diteliti menunjukkan bahwa partisipasi mahasiswa di setiap minggunya minimal adalah $60 \%$ dari jumlah mahasiswa secara keseluruhan.

Positive reward berupa nilai khusus bagi setiap mahasiswa yang berpartisipasi dalam dialog tampaknya membuat mahasiswa lebih termotivasi untuk mengikuti dialog secara aktif. Hal ini ditunjukkan dari adanya partisipasi mahasiswa baik dalam dialog di dalam kelas maupun dialog melalui FB pada setiap minggunya. Angka partisipasi melalui FB yang lebih besar dari dialog dalam kelas secara kuantitas disebabkan oleh waktu yang lebih banyak tersedia.
Perkuliahan yang hanya menyediakan waktu 3 sks (150 menit), seandainya semua mahasiswa peserta perkuliahan memiliki niat untuk berpartisipasi dalam dialog, tidak mencukupi untuk mengakomodasi keinginan tersebut secara keseluruhan. Hal ini berbeda dengan kondisi dialog melalui FB, dimana mahasiswa hampir tidak memiliki keterbatasan waktu. Bahkan di waktu tengah malam mereka dapat menyalurkan keinginannya untuk mengajukan pertanyaan atau merespon pertanyaan teman-teman mereka, walaupun tentu saja respon balik belum tentu mereka dapatkan saat itu juga.

FB sebagai media komunikasi yang sangat banyak digunakan oleh masyarakat dalam waktu lima tahun terakhir terbukti dalam penelitian ini menjadi media komunikasi yang mudah diakses oleh mahasiswa. Dari keseluruhan mahasiswa yang menjadi subyek penelitian ternyata hanya satu mahasiswa yang tidak menjadi peserta dalam kelompok diskusi. Kondisi ini juga menguatkan penelitian yang dilakukan oleh Donlan (2014) dari University of Central Lancashire Inggris yaitu dari 112 responden mahasiswa ternyata $80 \%$ menyatakan senang untuk menggunakan FB sebagai media pendukung akademik. Tentu saja dalam penelitian ini, keikutsertaan mahasiswa tidak hanya dipengaruhi oleh kesenangan mereka terhadap FB melainkan juga reward nilai yang diberikan.

Penggunaan teknologi internet juga
dapat mengajarkan kemampuan berkomunikasi secara efektif. Salah satu caranya menurut Moreno (2010) adalah dengan membuat suatu lingkungan yang aman bagi diskusi secara on line. Jumlah partisipan yang selalu jauh lebih besar pada dialog melalui FB daripada dialog di dalam kelas mengindikasikan adanya lingkungan dialog yang aman sepeti diungkapkan Moreno di atas. Lebih banyaknya waktu menguatkan kekondusifan untuk berdialog. Rasa aman 
mahasiswa dalam dialog dapat teramati dari bagaimana variasi tema yang dibahas, tidak adanya dialog negatif (ungkapan yang saling menyakiti) serta santainya bahasa yang digunakan. Contoh dari kondisi tersebut dapat diamati pada Gambar 1 berikut.

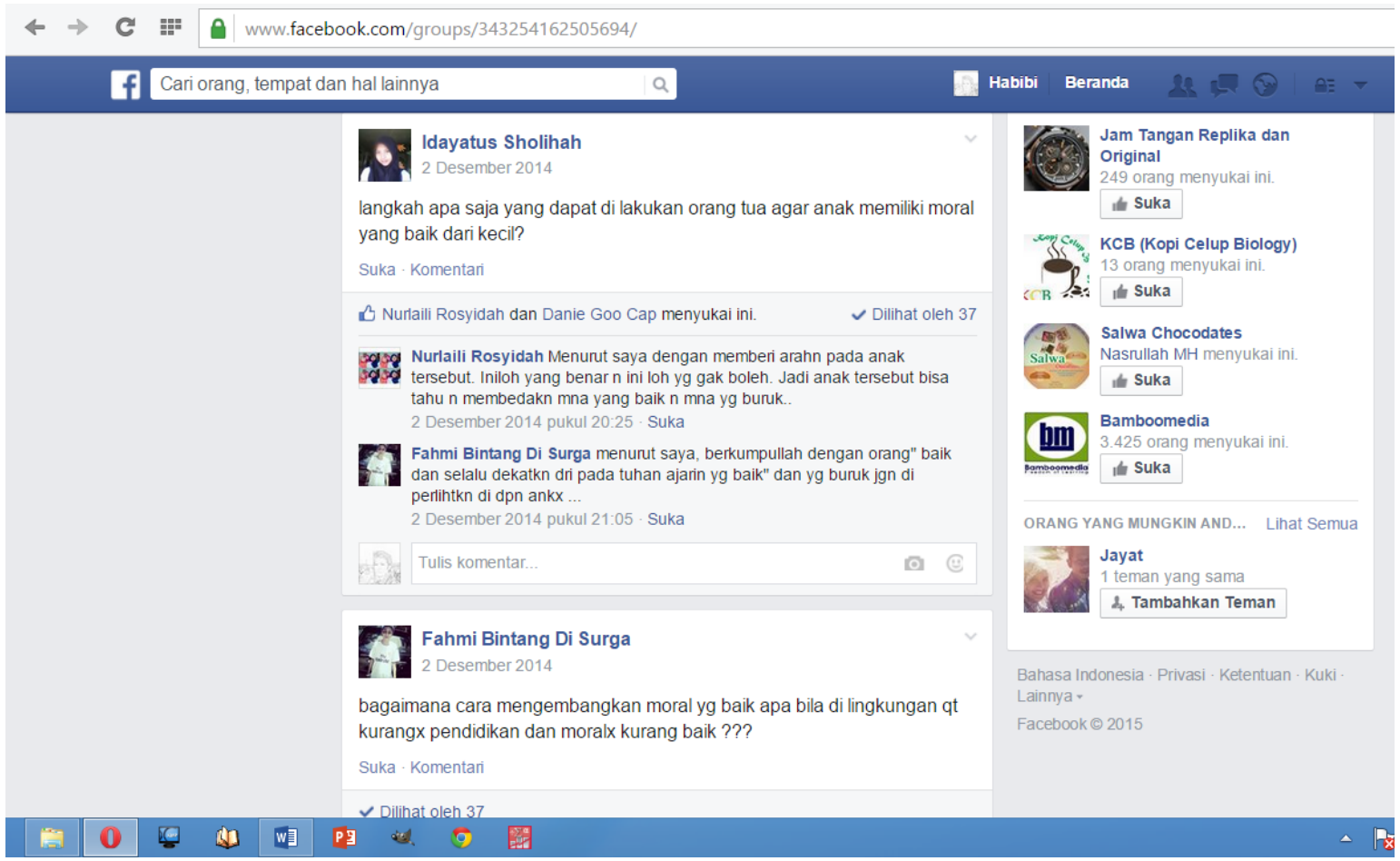

(Sumber: $\underline{w w w . F a c e b o o k . c o m ~ t a n g g a l ~} 2$ Desember 2014)

Gambar 1. Salah Satu Dialog Mahasiswa di FB

Ungkapan mahasiswa yang bernama Nurlaili Rosyidah pada Gambar 5 di atas menjadi contoh rasa aman dalam dialog, "menurut saya dengan memberi arahan pada anak tersebut. Iniloh yang benar dan iniloh yang gak boleh. Jadi anak tersebut bisa tahu dan membedakan mana yang baik dan mana yang buruk." Bahasa yang tidak begitu formal menunjukkan bahwa secara psikologis mahasiswa tersebut berada dalam kondisi santai dan tidak tertekan.

\section{Kepercayaan Diri Mahasiswa Mengikuti Dialog}

Efikasi diri mahasiswa dalam dialog perkuliahan, berdasarkan hasil eksplorasi penyebab permasalahan kecilnya partisipasi mahasiswa dalam dialog perkuliahan, menjadi masalah yang paling utama. Oleh karena itu tujuan kedua dari penelitian ini adalah mengetahui perubahan efikasi diri mahasiswa dalam dialog perkuliahan setelah penerapan positive reward dan Facebook.

Berdasarkan data hasil pengisian lembar efikasi diri mahasiswa dalam perkuliahan kemudian ditabulasi kemudian didapatkan seperti pada Tabel 2 berikut ini. 
Tabel 2. Tabulasi Nilai Efikasi Diri Mahasiswa dalam Dialog Perkuliahan

\begin{tabular}{|c|c|c|c|c|c|c|c|c|c|c|c|c|c|c|c|c|c|c|c|c|c|c|c|c|c|c|}
\hline \multirow[t]{2}{*}{ NAMA MAHASISWA } & \multicolumn{12}{|c|}{ Efikasi awal } & \multicolumn{12}{|c|}{ Efikasi Akhir } & \multirow{2}{*}{ JEAw } & \multirow[t]{2}{*}{ JEAk } \\
\hline & 1 & 2 & 3 & 4 & 5 & 6 & 7 & 8 & & 10 & 11 & & 1 & 2 & 3 & 4 & 5 & 6 & 7 & 8 & $9:$ & \begin{tabular}{l|l}
10 & 1 \\
\end{tabular} & \begin{tabular}{l|l}
11 & 1 \\
\end{tabular} & 12 & & \\
\hline Halifa (dalila imoet) & 4 & 3 & 4 & 4 & 3 & 3 & 3 & 4 & 3 & 3 & 3 & 4 & 5 & 3 & 5 & 5 & 3 & 3 & 5 & 5 & 3 & 3 & 5 & 5 & 41 & 50 \\
\hline Fatmawati (waty d'graceful) & 3 & 4 & 4 & 3 & 4 & 3 & 3 & 3 & 3 & 4 & 3 & 4 & 4 & 4 & 4 & 4 & 4 & 3 & 3 & 4 & 3 & 4 & 4 & 4 & 41 & 45 \\
\hline Irma (irma azja) & 4 & 4 & 2 & 2 & 3 & 2 & 3 & 3 & 3 & 2 & 3 & 3 & 4 & 5 & 2 & 2 & 3 & 2 & 4 & 4 & 3 & 2 & 3 & 3 & 34 & 37 \\
\hline Winda (wienda) & 4 & 4 & 4 & 3 & 2 & 2 & 3 & 3 & 2 & 4 & 5 & 5 & 4 & 2 & 4 & 4 & 2 & 2 & 3 & 3 & 2 & 4 & 5 & 2 & 41 & 37 \\
\hline maliaty (alia) & 2 & 4 & 3 & 3 & 2 & 2 & 4 & 3 & 2 & 3 & 4 & 4 & 2 & 4 & 3 & 3 & 2 & 2 & 5 & 5 & 2 & 3 & 5 & 5 & 36 & 41 \\
\hline suci fitri (shufia mawar) & 3 & 2 & 4 & 2 & 4 & 3 & 4 & 4 & 3 & 3 & 4 & 3 & 3 & 2 & 4 & 2 & 4 & 4 & 4 & 4 & 3 & 3 & 4 & 3 & 39 & 40 \\
\hline ummu r (ummu rofika) & 2 & 4 & 4 & 3 & 3 & 2 & 4 & 4 & 3 & 3 & 4 & 2 & 2 & 4 & 4 & 3 & 3 & 2 & 4 & 4 & 3 & 3 & 4 & 2 & 38 & 38 \\
\hline nur aini (aini ingin dimengerti) & 2 & 2 & 2 & 3 & 1 & 1 & 3 & 3 & 3 & 4 & 3 & 4 & 3 & 3 & 4 & 3 & 1 & 1 & 3 & 3 & 3 & 4 & 3 & 4 & 31 & 35 \\
\hline meiliana (meilia angelyca) & 4 & 4 & 4 & 3 & 4 & 3 & 4 & 4 & 3 & 4 & 3 & 4 & 4 & 3 & 4 & 3 & 4 & 3 & 4 & 4 & 3 & 4 & 3 & 4 & 44 & 43 \\
\hline ulfatus (ulfatus sarifah al hazin uphe luphe) & 4 & 4 & 4 & 4 & 4 & 3 & 4 & 3 & 3 & 3 & 4 & 4 & 4 & 4 & 4 & 3 & 4 & 3 & 4 & 3 & 3 & 3 & 4 & 2 & 44 & 41 \\
\hline nur azizah (azizah) & 3 & 3 & 3 & 4 & 2 & 2 & 3 & 3 & 2 & 3 & 3 & 4 & 4 & 3 & 3 & 4 & 2 & 2 & 3 & 3 & 2 & 3 & 3 & 5 & 35 & 37 \\
\hline hadi (hadi yohui) & 4 & 4 & 3 & 3 & 4 & 3 & 3 & 3 & 3 & 4 & 4 & 5 & 4 & 4 & 5 & 3 & 4 & 3 & 3 & $4 \mid$ & 3 & 5 & 4 & 5 & 43 & 47 \\
\hline siti nurul (nurul qomariyah milikAllah) & 3 & 4 & 3 & 5 & 4 & 4 & 4 & 4 & 3 & 4 & 4 & 3 & 5 & 4 & 5 & 5 & 4 & 4 & 4 & $4 \mid$ & 3 & 4 & 4 & 3 & 45 & 49 \\
\hline ana novi (ana noviana) & 3 & 4 & 4 & 3 & 4 & 3 & 4 & 4 & 3 & 4 & 4 & 3 & 5 & 4 & 5 & 3 & 4 & 3 & 4 & 5 & 3 & 4 & 4 & 2 & 43 & 46 \\
\hline siti aisiyah (ais yah) & 4 & 2 & 4 & 2 & 3 & 2 & 4 & 4 & 3 & 3 & 3 & 4 & 4 & 2 & 4 & 2 & 3 & 2 & 4 & 4 & 3 & 4 & 4 & 4 & 38 & 40 \\
\hline zainurrahman (zainorrahman (zen)) & 2 & 4 & 4 & 3 & 3 & 2 & 3 & 3 & 4 & 4 & 4 & 4 & 2 & 4 & 4 & 4 & 4 & 2 & 3 & 3 & 4 & 4 & 4 & 4 & 40 & 42 \\
\hline mustofa (ofa kocar kacir) & 4 & 4 & 5 & 5 & 4 & 3 & 4 & 4 & 5 & 4 & 4 & 3 & 4 & 4 & 5 & 5 & 4 & 3 & 4 & 4 & 5 & 4 & 4 & 3 & 49 & 49 \\
\hline diah ila (diah ila) & 4 & 3 & 4 & 3 & $3 \mid$ & 3 & 3 & 3 & 4 & 3 & 4 & 5 & 4 & 3 & 4 & 3 & 3 & 2 & 3 & 3 & 4 & 3 & 4 & 4 & 42 & 40 \\
\hline hamdani (danie goo cap) & 4 & 4 & 3 & 4 & 3 & 3 & 4 & 4 & 4 & 4 & 4 & 4 & 4 & 4 & 3 & 4 & 3 & 3 & 4 & 4 & 4 & 4 & 4 & 4 & 45 & 45 \\
\hline nurlaili (nurlaili rasyida) & 3 & 2 & 2 & 2 & 3 & 3 & 3 & 4 & 4 & 3 & 3 & 5 & 3 & 2 & 2 & 3 & 3 & 3 & 4 & 4 & 4 & 4 & 3 & 5 & 37 & 40 \\
\hline sri yuniati (sri yuniyati) & 4 & 4 & 4 & 4 & 3 & 2 & 3 & 3 & 3 & 4 & 2 & 4 & 4 & 4 & 4 & 4 & 3 & 2 & 5 & 5 & 3 & 4 & 2 & 4 & 40 & 44 \\
\hline auliyah (auliya ratunya alpard) & 4 & 4 & 3 & 2 & 2 & 2 & 3 & 4 & 2 & 2 & & 4 & 4 & 4 & 3 & 2 & 2 & & 3 & 4 & 2 & & & 4 & 34 & 34 \\
\hline & & & $77 \sqrt{7}$ & & & & & & & & & & & & & & & & & & & & & & 880 & 920 \\
\hline
\end{tabular}

Berdasarkan data tabulasi di atas ditemukan suatu gambaran umum mengenai kondisi efikasi diri mahasiswa sebelum penerapan positive reward dan facebook dan setelahnya. Secara umum efikasi diri mahasiswa dalam dialog perkuliahan mengalami peningkatan. Nilai total efikasi diri sebelum perlakuan adalah 880 sedangkan setelah perlakuan adalah 920. Nilai rata-rata efikasi diri sebelum perlakuan adalah 3,33 sedangkan rata-rata efikasi diri setelah perlakuan adalah 3,48.

Data efikasi diri awal dan efikasi akhir yang berupa data ordinal diuji perbedaannya dengan uji beda non parametrik yaitu uji Wilcoxson. Hasil pengujiannya dapat dilihat pada Lampiran X. Berdasarkan uji tersebut didapatkan kesimpulan bahwa efikasi diri mahasiswa dalam dialog perkuliahan mengalami perubahan secara signifikan ( $p$ valuenya adalah $0,12>0,05$ )

Peningkatan nilai efikasi diri mahasiswa dalam dialog menunjukkan bahwa proses dialog yang dilakukan oleh mahasiswa selama beberapa minggu melalui media jejarinf sosial cukup memberikan mereka keleluasaan untuk mengungkapkan pendapat tanpa beban yang berlebihan seperti layaknya ketika berdialog di dalam kelas. Berkurangnya tekanan inilah tampaknya yang membuat efikasi diri mahasiswa dalam berdialog mengalami peningkatan.

Penelitian yang dilakukan oleh Furutani, Kobayashi \& Ura (2009) menunjukkan bahwa interaksi melalui internet berpengaruh terhadap efikasi diri. Dalam penelitian tersebut dijelaskan bahwa bagi kelompok yang berasal dari strata sosial yang sama dampaknya adalah negative. Sebaliknya, interaksi melalui internet bagi kelompok masyarakat dari strata sosial yang berbeda ternyata berdampak positif. Mahasiswa yang merupakan kelompok remaja yang berasal dari keluarga dengan profesi dan strata sosial yang berbeda.

Peningkatan efikasi diri harapannya akan berdampak peningkatan pemahaman mahasiswa terhadap materi perkuliahan. Salah satu penelitian mengenai dampak efikasi diri terhadap kemampuan pemahaman siswa dilakukan oleh Lawson, Bank dan Logvin (2007) dari Arizona State University yang dilakukan pada mahasiswa Biologi. Hasilnya 
menunjukkan bahwa efikasi diri berkorelasi positif dengan pemahaman mahasiswa. Juga dijelaskan bahwa efikasi diri dapat digunakan sebagai predictor yang kuat bagi kemampuan mahasiswa untuk memahami materi perkuliahan.

\section{KESIMPULAN}

Kesimpulan yang dihasilkan dalam penelitian ini adalah sebagai berikut:

1. Rata-rata jumlah mahasiswa yang berpartisipasi dalam dialog melalui facebook dua kali lipat jumlah mahasiswa yang berpartisipasi dalam dialog kelas.

2. Efikasi diri mahasiswa dalam dialog perkuliahan mengalami perubahan secara signifikan (dengan menggunakan uji Wilcoxon nilai $\mathrm{p}$ value adalah $0,12>0,05)$.

\section{SARAN}

Berdasarkan hasil penelitian ini jumlah mahasiswa yang aktif dalam perkuliahan ataupun melalui facebook mengalami peningkatan, demikian juga dengan kepercayaan diri mahasiswa untuk mengikuti dialog. Namun sebenarnya penelitian ini belum mengevaluasi bagaimana kualitas pertanyaan dan pendapat mahasiswa dalam dialog. Berdasarkan teori Vygotsky mengenai mediasi sosial untuk meningkatkan kemampuan berbikir menyatakan bahwa dialog yang membangun kualitas berpikir adalah dialog yang mengarahkan mereka pada zona proximal, artinya berada di atas kemampuan mahasiswa saat ini. Ditinjau dari segi korelasi dengan konten perkuliahan dan logika pernyataan yang disampaikan kita dapat mengetahui apakah dialog tersebut memang benarbenar berkualitas. Untuk itu diperlukan penelitian lebih lanjut.
DAFTAR RUJUKAN

Branch, Robert M. 2009. Instructional Design : The ADDIE Approach. New York: Springer.

Broome, Benjamin J. 2009. Dialogue Theories. Encyclopedia of Communication Theory. California: SAGE Publication, Inc .

Chapin, Shuzane H. O'connor, catherine \& Anderson, Nancy C. 2003. Using Math Talk to Help Student Learn. Sausalito : Mathsolution Publication.

Domjan, Michael. 2010. The Principle of Learning and Behavior. Edisi keenam. Belmont : WADSWORTH Cengage Learning.

Dunlan, Leah. 2014. Exploring the views of students on the use of Facebook in university teaching and learning. Journal of Further and Higher Education. Vol. 38. No. 4. Hal: 572-588.

Furutani, Kaichiro. Kobayashi, Tetsuro. Ura, Mitsuhiro. 2009. Effects of Internet use on self-efficacy: perceived network-changing possibility as a mediator. AI and Society. Vol. 23 Issue 2. Hal. 251263.

Gaffney, Amy L. 2011. Measuring Students Self Efficacy for Communication. iJADE. Vol. 30. No. 02. Hal. 211-225.

Habibi. 2012. Pengantar Teori Belajar. Sumenep : UNIJA Press.

Habibi. Anekawati, Anik \& Faizah, Lutfiana F. 2010. Permasalahan Pembelajaran IPA SMP/MTs di Kabupaten Sumenep. Sumenep : Universitas Wiraraja.

Lane, Derek R. 2009. Communicationwith Students to Enhance Learning. Encyclopedia of Classroom Learning. Detroit: Gale Cengage Learning.

Lawson, Anton E. Bank Debra L. Logvin, Marshall. 2007. SelfEfficacy, Reasoning Ability, and Achievement in College Biology. 
Journal of Research in Science Teaching. Vol. 44. No. 5. Hal.706724.

Moreno, Roxana. 2010. Educational Psychology. New Mexico: John Woley \& Sons, Inc.

Omrod, Jeanne E. 2012. Human Learning. Edisi Keenam. Boston : Pearson.

Prescott. Julie. 2014. Teaching Style and Attitudes toward Facebook as an Educational Tool. Active Learning in Higher Education. Vol. 15. No. 2. Hal: 117-128.

Schunk, Dale H. 2012. Learning Theories, an Educational Perspective, edisi keenam. Boston: Pearson.

Setyowati, A. Subali, B. \& Mosik. 2011. Implementasi Pendekatan Konflik Kognitif dalam Pembelajaran Fisika untuk Menumbuhkan Kemampuan Berpikir Kritis Siswa SMP Kelas VIII. Jurnal Pendidikan Fisika Indonesia. Vol 7. No. 2. Hal: 89-96.

Ventura, Rafael \& Quero, M.J. 2013. Using Facebook in University Teaching: A Practical Cased Study. Procedia-Social and Behavioral Sciences. Vol. 8. Hal: 1032-1038. 